\title{
Correction to: Evaluation of antioxidant, anti-hemolytic, cytotoxic effects and anti- bacterial activity of selected mangrove plants (Bruguiera gymnorrhiza and Heritiera littoralis) in Bangladesh
}

Md. Adnan Karim¹, Md. Aminul Islam, Md. Muzahidul Islam¹, Md. Saidur Rahman', Sharmin Sultana', Satyajit Biswas ${ }^{1}$, Mohammad Jakir Hosen ${ }^{2}$, Kishor Mazumder ${ }^{3}$, Md. Masuder Rahman $^{4}$ and Md. Nazmul Hasan ${ }^{1 *}$

\section{Correction to: Clin Phytosci \\ https://doi.org/10.1186/s40816-020-0152-9}

In the original publication of this article [1], an author name was misspelt. Instead of Kishore Mozumder, the author name should be Kishor Mazumder.

The original article has been corrected.

\section{Author details}

'Department of Genetic Engineering and Biotechnology, Faculty of Biological Science and Technology, Jashore University of Science and Technology, Jashore, Bangladesh. ${ }^{2}$ Department of Genetic Engineering and

Biotechnology, Shahjalal University of Science and Technology, Sylhet, Bangladesh. ${ }^{3}$ Department of Pharmacy, Faculty of Biological Science and Technology, Jashore University of Science and Technology, Jashore, Bangladesh. ${ }^{4}$ Department of Genetic Engineering and Biotechnology, Mawlana Bhasani Science and Technology University, Santosh, Tangail, Bangladesh.

Published online: 19 March 2020

\section{Reference}

1. Karim A, et al. Evaluation of antioxidant, anti-hemolytic, cytotoxic effects and anti-bacterial activity of selected mangrove plants (Bruguiera gymnorrhiza and Heritiera littoralis) in Bangladesh. Clin Phytosci. 2020;6:8. https://doi.org/10.1186/s40816-020-0152-9.

The original article can be found online at https://doi.org/10.1186/s40816020-0152-9.

*Correspondence: mnhasan1978@gmail.com

'Department of Genetic Engineering and Biotechnology, Faculty of Biological Science and Technology, Jashore University of Science and Technology,

Jashore, Bangladesh

Full list of author information is available at the end of the article

\section{Springer Open}

(๑) The Author(s). 2020 Open Access This article is licensed under a Creative Commons Attribution 4.0 International License, which permits use, sharing, adaptation, distribution and reproduction in any medium or format, as long as you give appropriate credit to the original author(s) and the source, provide a link to the Creative Commons licence, and indicate if changes were made. The images or other third party material in this article are included in the article's Creative Commons licence, unless indicated otherwise in a credit line to the material. If material is not included in the article's Creative Commons licence and your intended use is not permitted by statutory regulation or exceeds the permitted use, you will need to obtain permission directly from the copyright holder. To view a copy of this licence, visit http://creativecommons.org/licenses/by/4.0/. 